\title{
地上用太陽電池効率の理論考察
}

\author{
荒木建次 ${ }^{* 1}$, エヌ・ディー・エキンスダウケス ${ }^{* 2}$, 山口真史 ${ }^{* 2}$
}

\section{Analysis on Efficiency Limit of Terrestrial Photovoltaic}

\author{
Kenji Araki, N. D. Ekins-Daukes, and Masafumi Yamaguchi
}

\section{Synopsis}

Monolithic multi-junction solar cells are constrained in that the current output of the stack is limited to the current being generated in the worst performing cell. This becomes a problem when the spectral content of the radiation incident on the solar cell is different to the 'designed' spectrum. The terrestrial spectrum always changes by different sun height or air mass as well as fluctuation of aerosol density. The annual power generation is expected to be smaller than the designed one, due to the spectrum mismatching. This influence may be emphasized by the increase of the number of junctions, while the efficiency under the designed standard spectrum will be increased with the number of junctions. The annual efficiency of monolithic multi-junction solar cells of more than three junctions were calculated and compared. No distinct advantage with more than 5 junctions in view of annual and daily power generation. The practical efficiency limit in real terrestrial sunshine is a little above $50 \%$.

\section{1.緒 言}

太陽光発電は, 化石燃料の枯渇に備えた代替エネルギー 源として，また，地球環境問題の解決に向けたクリーンな エネルギー源として，21 世紀を担うものとして期待され ている．しかし，代替エネルギー源としては，さらなる低 コスト化が要求されている.太陽光発電システム価格に占 める太陽電池用材料およびセルの比重は大きく，この問題 は太陽光を集光することにより解決することは可能であ $3^{1), 2)}$. 業務用電力コストあるいは発電原価と競合する低 コスト太陽光発電を目指した場合, もともと密度の低いエ ネルギーを設置面積でカバーするといった太陽光発電の 性質上, 変換効率を高めないと架台やモジュールの構造 材，設置工事費用がコス卜の相当部分を占めることにな り，いくら太陽電池で低コス卜化を図ってもシステムとし ては依然高額なものになる.セルの高効率化の可能性およ び最近の研究成果から,どの程度の効率がどういった構成 のセルで実現できるかを論ずる.特に，従来論じられてい なかった地上太陽光スペクトルの変動が発電効率に与え る影響を定量的に論じる．

\section{2 . 発電効率理論計算方法 (静的な手法)}

太陽電池の場合, 良質な結晶と表面不活性化, 電極設計 がなされた場合, 半導体に吸収された光子は $100 \%$ 近い効 率で電子・正孔対 (キャリア) に変換されて外部に弚の キャリア数に対応した電流として取り出すことが可能で ある.ただし,バンドギャップを下回るエネルギーの光子 は吸収されない．

しかしながら，いくら光子の持つエネルギーが高くと も，外部に取り出せる電圧としてはバンドギャップ，より 正確には暗電流密度 (材料のバンドギャップと欠陥密度の 関数) から決まるダイオード電流が外部負荷に流れる電流 とバランスする電圧が外部に取り出せる上限電圧となる． 電力は負荷に流れる電流と負荷にかかる電圧との積であ るため, 太陽電池の理論効率を求める問題は, 与えられた 太陽光スペクトルから材料の欠陥密度およびバンド ギャップを変数とする最適值問題に還元することができる．

定性的には材料のバンドギャップが低いほど電流が稼 げるが電圧か下がるといったトレードオフな関係にある．

\section{4 年 5 月 27 日受付}

* 1 大同特殊鋼(姝)技術開発研究所 豊田工業大学受託研究員 (Research \& Development Lab., Daido Steel Co., Ltd. Visiting Researcher, Graduate School of Engineering, Toyota Technological Institute)

* 2 豊田工業大学大学院工学研究科, 工博 (Dr., Eng., Graduate School of Engineering, Toyota Technological Institute) 
そのため,多接合化といったアイデアが古くから提唱され ていた .これは,高いバンドギャップ材料で高エネルギー の光子を利用し，これに吸収されない低エネルギー光子を 低いバンドギャップ材料で電力に変換する方法である い わば,光子エネルギーをカスケード利用して, 高い変換効 率を実現するといった発想である この方法て既に $31.5 \%$ の高い変換効率 (標準条件) が実現されている3).

また，集光照射すれば外部負荷に流れる電流か増大する ため, ダイオード電流とバランスする電圧か増大する.出 力電流は単純に入射光子数に比例するため,電力としては 集光倍率に応じた比例以上に増大することになる．した がって，集光も変換効率を高めるのに有効である.上記多 接合技術と組み合わせ , $37.4 \% の$ 高効率が日米で既に実現 されている4),5).

\section{3 . 静的な手法による実現可能 効率の計算結果}

理論効率を求める計算は最適值問題に帰着されるが,実 際には材料の制約があるので理論通りの効率が得られる とは限らない.本章で, 材料特性による制約を考慮した実 現可能効率, および, 現状の研究レベルで試作品の効率が どこまて理論効率に肉薄しているかを論じる。

NREL(National Renewable Energy Laboratory) では，集光 動作に理想的なバンドギャップを明らかにするため，単一接 合太陽電池および多接合太陽電池のモデリングを行った6),7). 次世代超効率太陽電池として，3，4 接合構造太陽電池の 集光動作が考えられる ${ }^{8)}$. Kurtz ら ${ }^{9)}$ は，3，4 接合構造太
陽電池の変換効率に関して数値解析を行っている ${ }^{10,11)} .3$ 接合セルの集光動作に関しては，1.93eV (トップセル) / $1.42 \mathrm{eV}$ (ミドルセル) $/ 0.95 \mathrm{eV}$ (ボトムセル) の組み合わ せで，400 倍集光で効率 $46 \%$ が期待できる ${ }^{11)}$. 格子不整 合系として，Ge あるいは GaAs 基板上に $\mathrm{InGaP}$ (AlGaAs) / GaAs / InGaAs (P) を構成するか, Ge あるいは GaAs 基板上の $\mathrm{InGaP}$ (AlGaAs) / GaAs 2 接合セルと InP 基板 上の InGaAs (P) セルとの3 接合メカニカルスタックを構 成するかであろう.Ge基板上の格子整合系 $\mathrm{InGaP}(\mathrm{AlGaAs})$ $/ \mathrm{GaAs} / \mathrm{Ge} 3$ 接合セルは, 400 倍集光で効率 $42 \%{ }^{12)}$ が 期待できる.

4 接合構造太陽電池の理想効率の 4 接合層のバンド ギャップ依存性について述べる. 理論変換効率は, 各々, $52.5 \%$ である ${ }^{12)}$.

今回, 計算基準や動作条件がバラバラであった各種接合 構成における太陽電池の理論効率を見直し, 統一した条件 での比較を試みた . 結果は Table1のようになる . Table 1 にはこれまでに試作された最高効率のセルの効率も合わ せて示している.格子整合系の場合, 理論効率の $90 \%$, 格 子不整合系の場合, 理論効率の $80 \%$ が実際に到達してい るセル効率にほぼ相当する .これを敷衍すると, 現在国内 外で精力的に研究開発が進められている4接合セルの格子 整合系の場合には，47\%の効率実現か期待される .

\section{4.スペクトル変動を前提とした 多接合太陽電池動作動的モデル およびその検証}

Table 1. Comparison of efficiency among theoretical, achievable and achieved multi-junction solar cells under concentration operation.

\begin{tabular}{|c|c|c|c|c|c|c|}
\hline $\begin{array}{l}\text { Number of } \\
\text { Junction }\end{array}$ & Lattice Matched & Lattice Mismatched & $\begin{array}{l}\text { Theoretical } \\
\text { Efficiency }\end{array}$ & $\begin{array}{l}\text { Achievable } \\
\text { Efficiency }\end{array}$ & $\begin{array}{l}\text { Achieved } \\
\text { Efficiency }\end{array}$ & $\begin{array}{l}\text { Achieved/ } \\
\text { Theoretical }\end{array}$ \\
\hline $1-J$ & GaAs & & $34 \%$ & $29 \sim 30 \%$ & $27.8 \%$ & $81.8 \%$ \\
\hline \multirow[t]{8}{*}{$2-J$} & & $1.54 \mathrm{eV} / 0.94 \mathrm{eV}$ & $42 \%$ & $38 \%$ & & \\
\hline & & (GaAs / GalnAsP) & & & $30.2 \%$ & $71.9 \%$ \\
\hline & & $1.4 \mathrm{eV} / 0.72 \mathrm{eV}$ & $41 \%$ & $37 \%$ & & \\
\hline & & (GaAs / GaSb) & & & $32.8 \%$ & $80.0 \%$ \\
\hline & & $\mathrm{GaAs} / \mathrm{Si}$ & $38.5 \%$ & $35 \%$ & $31.0 \%$ & $80.5 \%$ \\
\hline & $1.4 \mathrm{eV} / 0.72 \mathrm{eV}$ & & $41 \%$ & $37 \%$ & & \\
\hline & $(\operatorname{InP} / \operatorname{InGaAs})$ & & & & $31.8 \%$ & $77.6 \%$ \\
\hline & $\operatorname{lnGaP} / \mathrm{GaAs}$ & & $35 \%$ & & $31.5 \%$ & $90.0 \%$ \\
\hline \multirow[t]{2}{*}{ 3-J } & & $\begin{array}{l}1.93 \mathrm{eV} / 1.42 \mathrm{eV} / 0.95 \mathrm{eV} \\
(\mathrm{InGaP} / \mathrm{GaAs} / \operatorname{InGaAsP}) \\
\operatorname{InGaP} / \operatorname{InGaAs} / \mathrm{Ge}\end{array}$ & $\begin{array}{l}46.5 \% \\
46.5 \% \\
\end{array}$ & $\begin{array}{l}42 \% \\
42 \% \\
\end{array}$ & $(42 \%)$ & $(90 \%)$ \\
\hline & $\begin{array}{l}\text { (Al)InGaP / } \\
\mathrm{GaAs} / \mathrm{Ge}\end{array}$ & & $42 \%$ & $38 \%$ & $37.4 \%$ & $89.0 \%$ \\
\hline $4-J$ & $\begin{array}{l}2 \mathrm{eV} / 1.42 \mathrm{eV} / \\
1.05 \mathrm{eV} / 0.7 \mathrm{eV} \\
((\mathrm{Al}) \operatorname{InGaP} / \mathrm{GaAs} \\
/ \mathrm{GalnNAs} / \mathrm{Ge})\end{array}$ & & $52.5 \%$ & $47 \%$ & $(47.3 \%)$ & $(90 \%)$ \\
\hline
\end{tabular}


多接合セルは各々の接合が直列接続されている関係で， 各々のセルの発電電流に不一致があると，氒の内の最も小 さい発電電流以上の電流を外部回路に流し得ない，一方， 自然の太陽光は基準スペクトルたとえばエアマス 1.5 での 全天スペクトル (AM1.5G) と，常に同じとは限らないし， 正確に言えば，集光セルの場合青空からの散乱日射を利用 できないため，沖縄など低緯度地域の夏至南中といえど も，この基準スペクトルに比べ短波長成分が不足する傾向 にある．加えて，日射スペクトルはたとえばFig.1 に示す ように季節により，また，時々刻々変動するものである． Fig.1は北緯 $35^{\circ}$ の地点で春分に於いて南中から日没までの 時角を等分割し，各々の時角においての法線面における直 達日射スペクトルを示す . 3 接合集光太陽電池を実際に屋 外て試験すると，集光，非集光いずれの場合でも日射状況 あるいは空の色により日射あたりの短絡電流および効率 が $20 \%$ 程度の幅で変動することが観測された . 具体的に は空の色が青くしたがって散乱成分が少ない大気条件で は効率および日射あたりの短絡電流が高く，逆に薄雲がか かったりなどして空の色が薄くなると日射あたりの短絡 電流や効率も低下した。

単一スペクトル基準を用いた静的な理論効率検討は,単 一の基準で比較できるのでセル研究開発にとっては有効 であるが,発電量の最大化を目指した装置開発に当たって は必ずしも適切な指針を与えるものではない . したがっ て，集光式太陽光発電をはじめとして多接合による高効率 セルを用いた発電装置の実用化か間近に迫った現状では 煩雑ではあるが動的な理論構築に踏み込まざるを得ない と考える

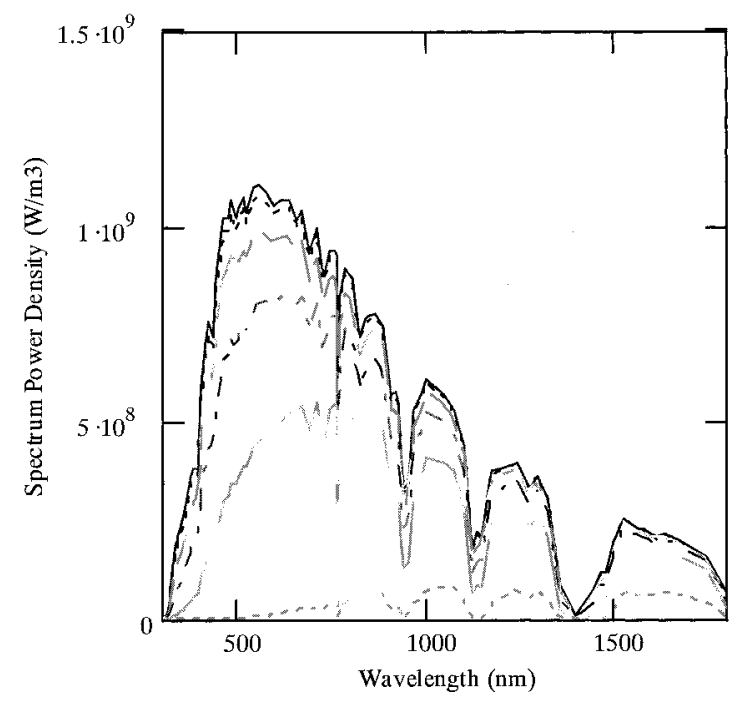

Fig.1. Daily spectrum change direct normal, clear sky. Each line indicates spectrum of the direct beam sunlight at equal division of time angles from noon to sunset in the equinox on N35 degree of latitude.
実際の太陽光では避けることができないスペクトル変 動を前提とした動的な発電効率理論の構築を試みる。

モデルは下記 2 ステップから成り立つ .

1 . 直達日射量からスペクトルを予測する .

2 .予測されたスペクトルからセル特性 (短絡電流， 効率) を算出する．

1.のスペクトルモデルに関しては経済性(発電量予測)， および日本の気象条件を考慮したスペクトル規格で議論 した内容 (論文等出版済み) と重複するので既出文献を紹 介するにとどめる ${ }^{2), 13), 14) ~ . ~}$

スペクトルがマッチングしていない場合, 短絡電流が低 下し FF (曲線因子) か増大する .この現象は Fig.2 で説明 できる .トップセル, ボトムセル, ミドルセル各々のI-V 特性を電圧軸に沿って重畳すれば出力のI - Vカーブが得 られる.しかしながら , スペクトルがマッチングしていな い場合, 最も短絡電流が少ない接合の短絡電流 (この場合 はトップセル) を越えた電流が流れないため，Fig.2 の下 図に示すように,最も短絡電流が大きいセル（この場合は ボトムセル) の電流が , ボトルネックとなっている接合の 短絡電流 (この場合はトップセル) に等しい地点となった ところから次の接合のI-Vカーブ (この場合はミドルセ ル) が重畳され, さらに, 弚の電流が再びボトルネックと なっている接合の短絡電流まで下がった地点から次のセ ル (この場合はトップセル) が重なるというように電圧が 合成されるため, 最終的には角張った I-Vカーブとなり， FF が増大することになる．定性的な表現では，ミスマッ チングがあまり大きくない範囲では過剩電流によりダイ オード特性の肩の部分が埋められるため, 谷の分, $\mathrm{FF}$ 補 償か続くということである .

スペクトル变化が発電特性に与える影響は, 厳密には非 線形の回路方程式を解かなければならないが,簡便には下 記モデルで計算できると考えられる．また，測定結果と照

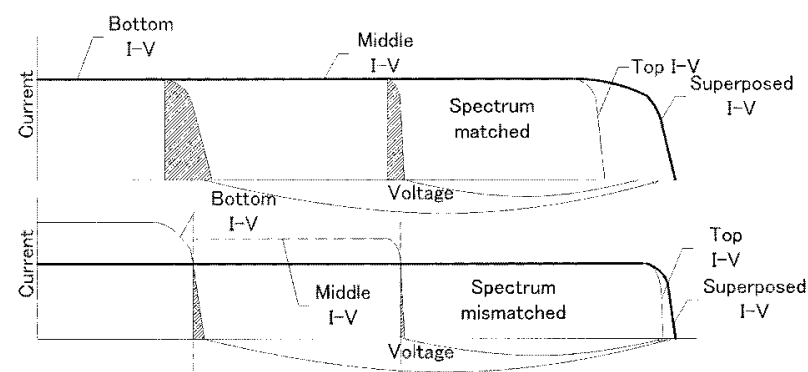

Fig.2. Superposition of $\mathrm{I}-\mathrm{V}$ curves of the stack of solar cells with and without presence of current mismatching. 
合した結果 ,この簡便なモデルで十分な精度が得られるこ とが実証された .

大筋の流れとして，下記考え方でスペクトル变動時の短 絡電流, FF，効率を求める.

短絡電流 : 3 接合の発電電流の内, 最小值を充てる.

効率: 直達日射量变動に伴う電圧, および上記短絡電流低 下を補正した後, 3 接合での平均出力電流と 3 接合の内最 大となる電流との比, および, $\mathrm{FF}$ 最大値と $\mathrm{FF}$ 最小値との 比の小さい方の比を掛け合わせる .ここに，FF 最小值は スペクトルが完全にマッチングした時の弚れ，FF 最大值 はスペクトルミスマッチングにより上昇しうる最大值の FF を示す. 実験上，ある程度以上にスペクトルのマッチ ングがずれると，FF も飽和するため，これを FF 最大值と する.かいつまんでいえば，FF 最大値までの範囲内にお いて，過剩電流により FFが補正されるという考え方であ る、言い換えれば，最大 FF を超えない範囲では過剩電流 が尽きるまで $\mathrm{V}_{\mathrm{pmax}}$ は引き延ばされるということである.

以下，数式を用いてモデルを説明するが，煩雑になるの を避けるため，数式はトップセルのみ記述する .ミドルセ ル，ボトムセルでの発電量も同樣に計算することができ る . 短絡電流を求めるにあたり，量子効率から分光効率 $\mathrm{A} / \mathrm{W}$ に変換する必要がある.この係数は下式で与えられる
(式1).

標準スペクトルでのトップセル, ミドルセル, ボトムセ ルでの発電電流を与え，これに対応する吸収端を求める。 ただし, 分光感度の空形状は矩形と想定する.吸収端に相 当する波長ベクトルの要素番号は下式で計算できる (式 2 〜 4). 積分は計算時間短縮のため, 台形公式を乥のまま 利用した .ここに，下添え字 $\mathrm{k}$ は波長ベクトルの要素番 号, 下添え字 $\mathrm{i}$ は時角の要素番号を示す. $\mathrm{x} 1, \mathrm{x} 2$ はトップ セル, ミドルセル, ボトムセルの分光特性を矩形密になっ ていると想定したとき,トップセル，ミドルセルの吸収端 に対応する波長ベクトルの要素番号を示す．

Indexstart は有効波長データベクトルの開始要素番号 , Indexend は有効波長ベクトルの終了要素番号を示す要素 番号である.さらに, rtop, rmiddle, rbottom はトップセ ル, ミドルセル, ボトムセルの AM1.5G における発電電流 比を表す $\mathrm{I}_{1.5}$ は AM1.5G における各波長でのスペクトル 密度を示す. $\lambda$ は波長である.

標準スペクトル，あるいは任意の時角での有効領域日射 強度は下式で表される (式 $5 ＼mathrm{~ 6) ~ . ~ R a d ~ は 有 効 波 長 領 域 ~}$ での日射強度, Radstd は AM1.5G 有効スペクトル領域で の日射強度を示す . $\mathrm{I}_{\mathrm{i}}$ はスペクトル強度 $\mathrm{I}$ の下添え字 $\mathrm{i}$ に 対応するある時角での分光スペクトル強度を表す．

$$
\begin{aligned}
& \mathrm{AA}:=\frac{1.6021773310^{-19} \cdot \text { coul }}{\left(299792458 \frac{\mathrm{m}}{\mathrm{sec}}\right) \cdot\left(6.626075510^{-34} \cdot \text { joule } \cdot \mathrm{sec}\right)} \\
& \text { ph00 : }=\text { AA } \frac{\mathrm{r}_{\text {top }}}{\mathrm{r}_{\text {top }}+\mathrm{r}_{\text {middle }}+\mathrm{r}_{\text {bottom }}} \cdot 0.5 \cdot \sum_{\mathrm{k}=\text { IndexStart }}^{\text {IndexEnd-1 }}\left(\lambda_{\mathrm{k}} \cdot \mathrm{I}_{1.5_{\mathrm{k}}}+\lambda_{\mathrm{k}+1} \cdot \mathrm{I}_{1.5_{\mathrm{k}+1}}\right) \cdot\left(\lambda_{\mathrm{k}+1}-\lambda_{\mathrm{k}}\right) \\
& \operatorname{phx}(\mathrm{x}):=\mathrm{AA} \cdot 0.5 \cdot \sum_{\mathrm{k}=\text { IndexStart }}^{\text {IndexStart+x }}\left(\lambda_{\mathrm{k}} \cdot \mathrm{I}_{1.5_{\mathrm{k}}}+\lambda_{\mathrm{k}+1} \cdot \mathrm{I}_{1.5_{\mathrm{k}+1}}\right) \cdot\left(\lambda_{\mathrm{k}+1}-\lambda_{\mathrm{k}}\right) \\
& \mathrm{x} 1:=\sum_{\mathrm{x}=0}^{\text {IndexEnd-IndexStart-1 }}(\mathrm{phx}(\mathrm{x}) \leq \mathrm{ph} 00) \\
& \operatorname{Rad}_{i}:=0.5 \cdot \sum_{k=0}^{N u m-2}\left\lceil\left(I_{i}\right)_{k}+\left(I_{i}\right)_{k+1}\right]^{\cdot\left(\lambda_{k+1}-\lambda_{k}\right)} \\
& \operatorname{Rad}_{\mathrm{std}}:=0.5 \cdot \sum_{\mathrm{k}=0}^{\mathrm{Num}-2}\left\lceil\left(\mathrm{I}_{1.5}\right)_{\mathrm{k}}+\left(\mathrm{I}_{1.5}\right)_{\mathrm{k}+1}\right]^{\cdot\left(\lambda_{\mathrm{k}+1}-\lambda_{\mathrm{k}}\right)}
\end{aligned}
$$


AM1.5G ヘのスペクトルマッチングでの発電電流は式 7 で計算できる．発電電流には日射エネルギーは直接関係せ ず,光子数の積分に比例することに注意されたい．この式 を敷衍することにより，任意時角でのトップセル，ミドル セル , ボトムセルでの発電電流量を求めることができる . 実際のスペクトルにおける短絡電流は，上記各接合におけ る発電電流の最小值として求められる.

任意時角での開放電圧は下式で補正される (式 8).Voc0 は標準日射強度における開放電圧, 関数 Match(x) は, 日 射量に比例した理想セルの発電電流を与えるもので,下式 により計算される (式 9) . ph はスペクトルマッチングし た場合の発電電流である。

任意時角での発電効率は下式で表される (式 10) . min は引数の内 , 最小の要素を選 3 ; 関数である. minJ , maxJ はベクトル (ph1, ph2, ph3) の最小要素, 最大要素を示 す . minJ はスペクトルマッチングしていないときの短絡 電流に一致する . FFmatch , FFmax はスペクトルマッチング した時のFF，およびスマッチしたときのFF最大值を示す．

FF 増大量を与える上式を Fig.3 を用いて説明する . Isc
と Ipmax はほぼ等しい,またはスペクトルミスマッチング を起こしても Isc/Ipmax の比は変化しないと仮定すると， FF は Vpmax の比として表現される (式 11～13).した がって ,ミスマッチング時 ,マッチング時に相当する $\mathrm{V}_{\mathrm{pmax}}$ と $\mathrm{V}_{\mathrm{pmax} 0}$ との比は式 14 で表現される .これは，FF が上限 值を越えない範囲での FF 増大を与える式に一致する .

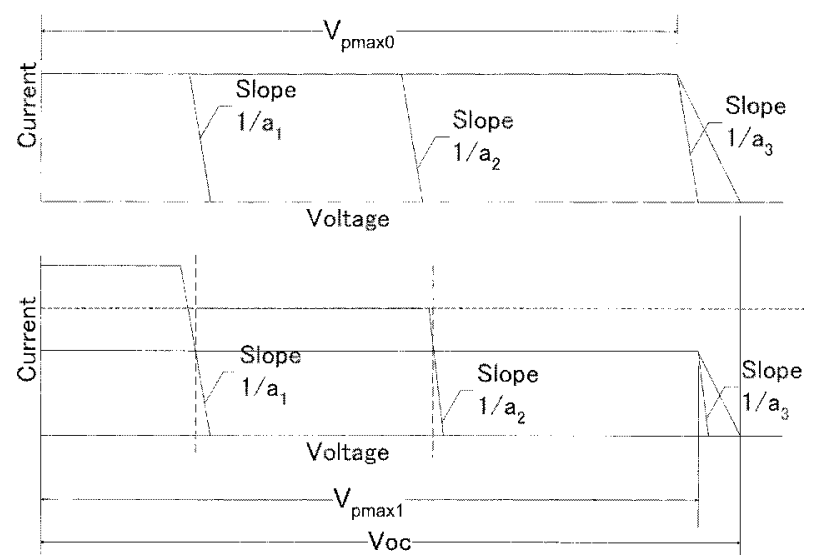

Fig.3. Approximation of $\mathrm{I}-\mathrm{V}$ curves of solar cells for linear calculations.

$$
\begin{aligned}
& \mathrm{ph}:=\mathrm{AA} \cdot \frac{1}{3} \cdot 0.5 \cdot \sum_{\mathrm{k}=\text { IndexStart }}^{\text {IndexEnd-1 }}\left(\lambda_{\mathrm{k}} \cdot \mathrm{I} 1.5_{\mathrm{k}}+\lambda_{\mathrm{k}+1} \cdot \mathrm{I} 1.5_{\mathrm{k}+1}\right) \cdot\left(\lambda_{\mathrm{k}+1}-\lambda_{\mathrm{k}}\right) \\
& \operatorname{Radadj}_{i}:=\frac{\operatorname{Voc} 0+3 \cdot 0.027 \text { volt } \cdot \ln \left(\frac{\operatorname{Rad}_{\mathrm{i}}}{100 \frac{\mathrm{mW}}{\mathrm{cm}^{2}}} \cdot \frac{\operatorname{Match}\left(\operatorname{Rad}_{\mathrm{i}}\right)}{\min \mathrm{J}_{\mathrm{i}}}\right)}{\operatorname{Voc} 0} \\
& \operatorname{Match}(\mathrm{x}):=\frac{\mathrm{ph}}{100 \frac{\mathrm{mW}}{\mathrm{cm}^{2}}} \cdot \mathrm{x} \\
& \text { EFFadj }_{i}:=\min \left[\frac{\left(\text { meanJ }_{i}-\text { minJ }_{i}\right) \cdot(1-\text { FFmatch })}{\text { meanJ }_{i}}+1, \frac{\text { FFmax }_{i}}{\text { FFmatch }}\right] \cdot \text { Radadj }_{j} \\
& V \operatorname{pmax} 1:=\operatorname{Voc}-(\mathrm{a} 1+\mathrm{a} 2+\mathrm{a} 3) \cdot \min J \\
& \mathrm{Vpmax} 0:=\mathrm{Voc}-(\mathrm{a} 1+\mathrm{a} 2+\mathrm{a} 3) \cdot \mathrm{meanJ} \\
& \text { Vpmax }:=\text { Voc } \cdot \text { FFmatch } \\
& \frac{V p \max 1}{V p \max 0}:=1+\frac{(\text { meanJ }-\min J) \cdot(1-\text { FFmatch })}{\text { meanJ }}
\end{aligned}
$$


直達日射の場合, 日射スペクトルの变動は Fig.1 に示し たように散乱成分の多寡で説明できる . 散乱成分が大きく なるにつれ直達日射量が低下するため, 直達日射量を説明 変数として短絡電流，およひ効率を目的変数とさせれば， これらは直接観測できる基本的な測定量であるため，実用 上便利であるだけでなく，上記大気パラメータの变動の影 響を受けにくくなるといった利点もある。ただし，注意を 要するのは地球と太陽との距離が季節により変動するた め，この関係はある特定の日しか成立しないことである たとえば， 6 月における日射強度 $850 \mathrm{~W} / \mathrm{m}^{2}$ の日射スペク トルは 12 月における $910 \mathrm{~W} / \mathrm{m}^{2}$ と大気散乱の状況，言い換 えればスペクトルがほぼ同じ状況である.ちなみに ,太陽 と地球とが最接近するのは 0 を起点とする Day Number で 3 (1 月 4 日), 光のときの日射強度補正係数は 1.035 , 最 も離れるのは 0 を起点とする Day Number にて 181 ( 6 月 2 日) で，谷のときの日射補正係数は 0.967 である.この意 味で, 直達日射量 (法線面直達日射量) に加え, 法線面全 天日射量も利用できる環境にあれば, 説明変数を直達日射 量とせず，直達成分比 (法線面全天日射に対する直達日射 量比) とした方が，Day Number に影響を受けない指標と なるため，便利かもしれない．

検証には非集光 (法線面全天日射を利用)，集光 (直達 日射を利用) で行った．法線面全天日射を使ったのは，ア ルベドの分光反射率の影響を避けたためである.非集光で の短絡電流モデル計算值と測定值との関係をFig.4に ,効 率のモデル計算值と測定值との関係を Fig.5に , 集光での

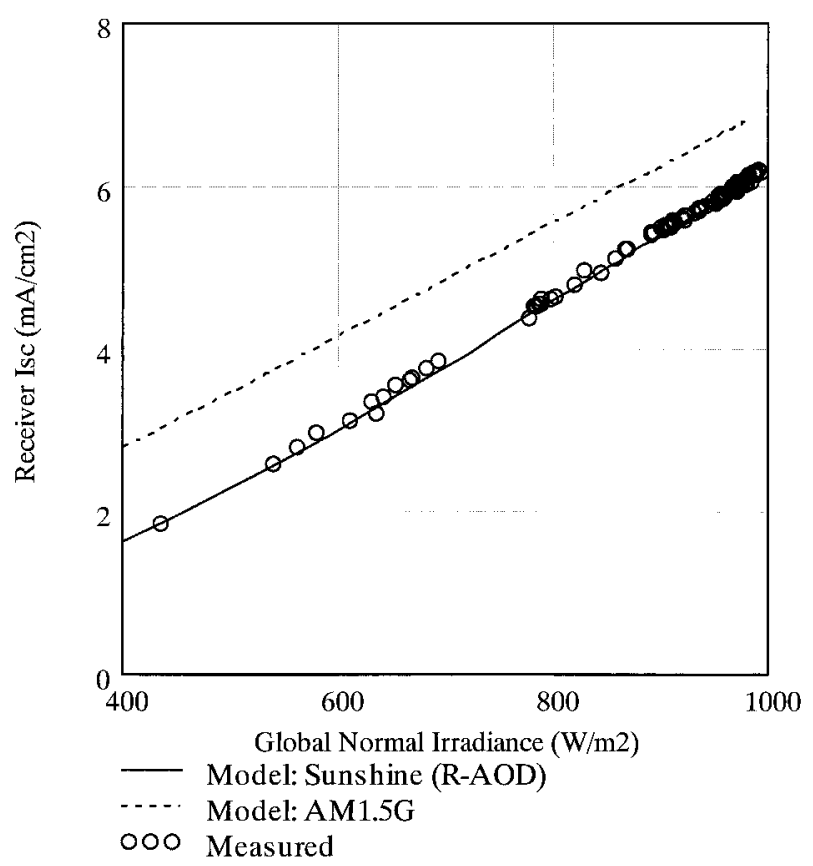

Fig.4. Measured and calculated Isc of 3-J solar cell tracking flatplate operation.

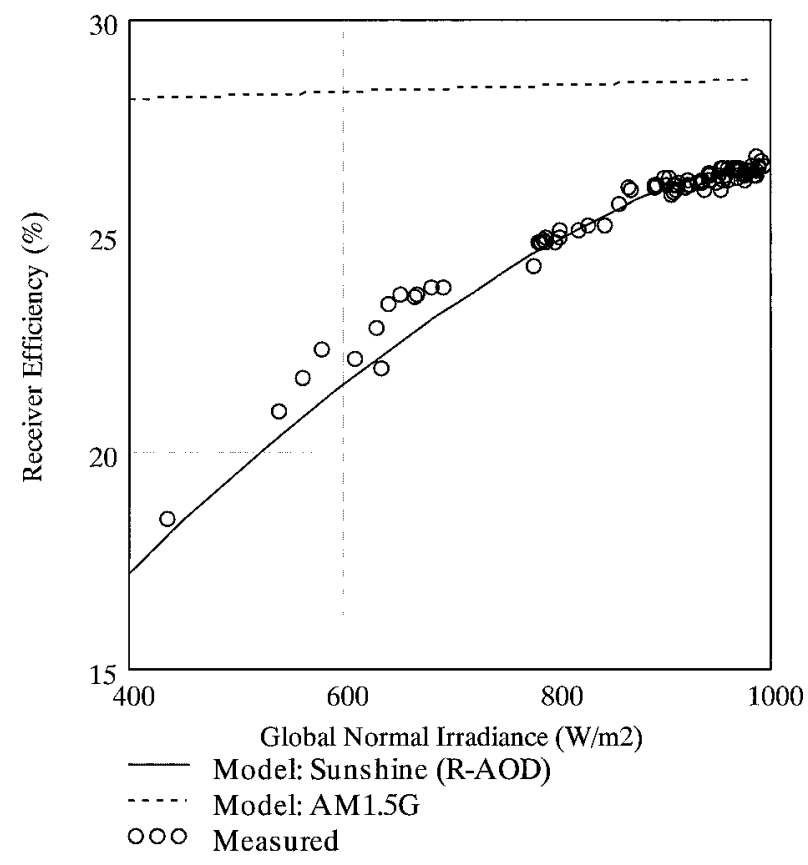

Fig.5. Measured and calculated efficiency of 3-J solar cell tracking flat-plate operation.

結絡電流モデル計算值と測定值との関係を Fig.6に 効率 のモデル計算値と測定値との関係を Fig.7 に示す .なお， 各々のグラフに於いて , AM $1.5 \mathrm{G}$ は大気層の厚さが鉛直面 の 1.5 倍 (エアマス 1.5 ) における水平面全天日射標準ス ペクトルであり，IEC 規格に基づいた数表を用いた．RAOD スペクトルとは, 従来の標準スペクトルが大気中の 混濁粒子密度を過大評価していたのではないかとの観測に

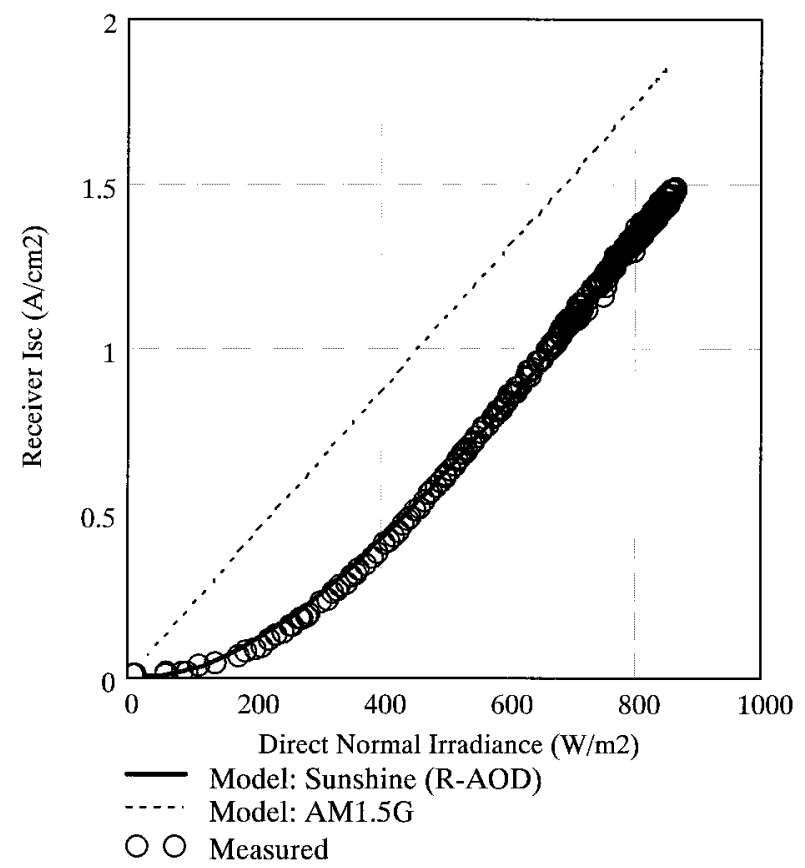

Fig.6. Measured and calculated Isc of 3-J solar cell under 400X concentration operation. 


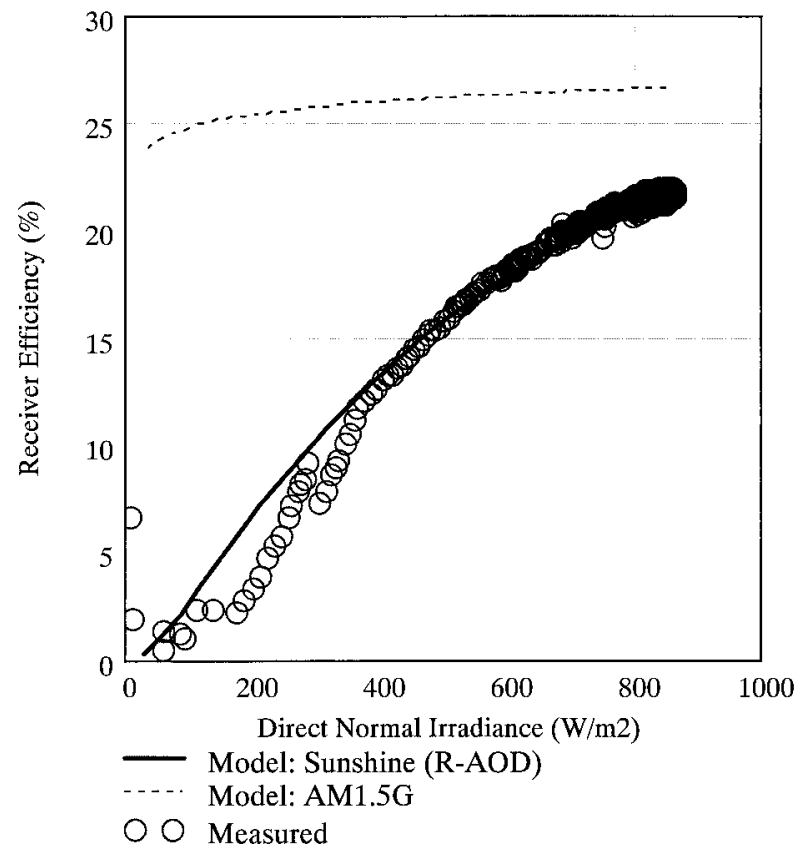

Fig.7. Measured and calculated efficiency of concentrator module (32 receivers connected in series).

基づき,世界各国で再検討されているスペクトル案の総称 であるが，今回は，気象庁観測の国内 14 箇所における大 気透過率測定データの月変動データをフィッティングさ せて大気パラメータを求めて算出した値を用いて計算を 行った・どちらもモデルとよく一致している．

本研究は愛知県内の若手研究者グループであるシラクサ (世界で初めて太陽光集光器を実用化したアルキメデスに 敬意を表し光の故郷から命名した) に引き継がれ，半導体 のモデリングから観測結果のデータベース技術，日射計測 および乥のモデル化技術など異分野融合の研究に発展し ている ${ }^{15)}$.

\section{5 . スペクトル変動を前提とした太陽 電池の理論上限効率の再検討}

従来,太陽電池では接合数を増やせば増やすほど変換効 率が単調に増大するとされてきた。しかしながら，これま で論じたように，理論的にも実験上からもスペクトル変動 によるミスマッチングによる損失が顕著に作用すると考 えられる.このスペクトル変動に伴う太陽電池動作モデル を敷衍すると，徒に接合数を増大しても年間発電量は増大 するとは限らないといった，従来の定説を覆す結論か暗示 される

具体的な計算方法としては, (1) 各々のスペクトルおよ び負荷条件での発電量計算を行い,この発電量が最大とな る負荷条件を求める, (2) 太陽高度の季節変動, 日間変動 ごとに変化する最適負荷条件での最大出力を積算する，
(3) 上記積算出力が最大になるようにバンドギャップの組 み合わせを最適化するといったネストされた動的計画法 を使う.計算時間としては，通常の PC (クロック $500 \mathrm{MHz}$ ) で数日である .

Fig.8 にスペクトル変動を考慮して各接合数の太陽電池 における最適設計計算を行い, 時々刻々変動するスペクト ルのもとでの理論効率上限を算出し，接合数を増した場 合 , 本当に効率が増大するかを検証した結果を示す .スペ クトルが変動する地上用太陽電池の場合, 5 接合以上接合 数を増やしてもメリットがないことが導かれた .弚の効率 理論上限值としては $50 \%$ であった .この計算では材料に よる制約を全く加えておらず，したがって，実現可能な効 率としては3章て議論した格子不整合系のアナロジーを使 うのが適当であろうと考えられる.したがって, 年間平均 効率で議論した場合, 実現可能な值として $40 \%$ 程度の効 率が見込まれる .この值の多臭については議論が分かれる ところであるが , 現時点での市販モジュールの最高値が $17.5 \%{ }^{16)}$,年間平均効率としては定格の $65 \%$ 程度であるこ とを考えれば, 現行品の 3.5 倍の発電量となり，十分に魅 力的なターゲットと考える .

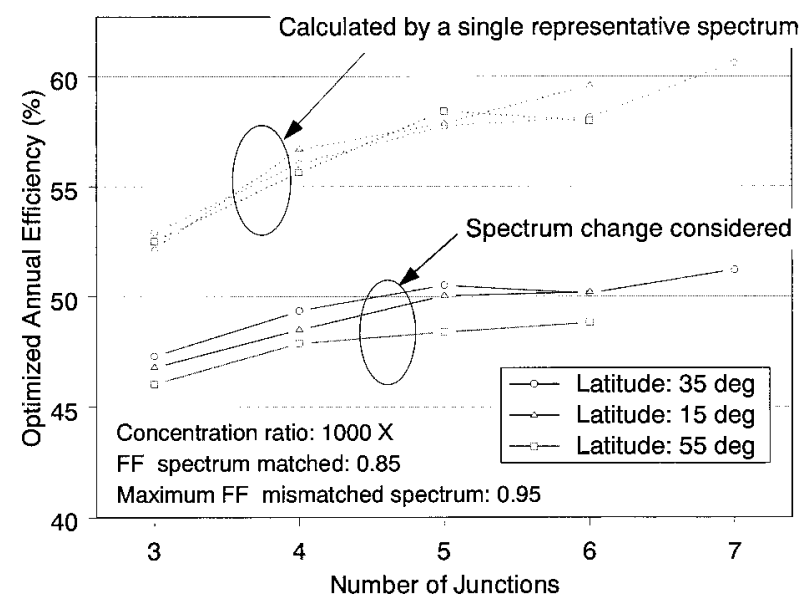

Fig.8. Optimized annual efficiency by two calculations classical single spectrum representation vs. calculation by weighted every spectrum.

\section{6.スペクトル変動により制約 される理論限界を越えるには}

これまで論じたに多接合セルがスペクトル変動に対し て発電効率が低下する問題, およびこの問題が接合数の増 大につれて顕著になることについては, 定量的な研究は著 者らか嚆矢となるが, 定性的には古くから議論されてきた ことである.主に高効率太陽電池の理論を研究しているグ ループから解決策につながる可能性の提案がいくつかな されている . 
豪州のグループからはセルを LED として動作させ , 光 エネルギーに逆変換して過剩電流の伝達を行うことを提 唱している.この場合，キルヒフォッフの法則の制約を受 けないので,過剩電流をエネルギーとして外部に出力する ことが可能となる ${ }^{17)}$. 問題は具体的な材料およびセル構 造についての提唱がまだできていないことである．

著者らは,スイッチング素子を外付けして過剩電流発生 に伴う電圧上昇 (接合部の逆バイアス) を検出して過剩電 流を外部回路に流して電力として取り出すといった方法 を提唱している ${ }^{18)}$.この方法は低コストで実現容易であ るが，残念ながら，現時点では負荷抵抗が低い領域では動 作するものの, 最大出力地点の負荷条件では電圧損失が発 生し，メリットを見出すに至っていない．

本質的な解決にまで至らなくとも，この効果を緩和する 方法もある.著者らは,バンドギャッフ設計だけでも効率 をさほど落とすことなくスペクトル変化に対し頑健で, 低 緯度地帯から高緯度地帯まで同じバンド設計でカバーで きるといった ,スイートスポット領域が存在することを発 見している ${ }^{13)}$. また，活性領域の膜厚を調整することに より, 各接合の分光感度にオーバーラップ領域を設けるこ とにより,スペクトル変動に対する頑健度を向上させるこ とができることも数値計算上から見いだしている ${ }^{19)}$.

\section{7 . 結 論}

多接合セルの効率につき従来の静的な手法の再見直し を行うとともに これまでに発表された各種構成のセルの 効率実現值と比較した . 格子整合系としては理論効率の 90 \%が, 格子不整合系としては理論効率の $80 \%$ \%゙実現さ れていることを確認した .

太陽光スペクトルか時々刻々また，季節や天候により変 化することを考えると，動的なモデルによる効率理論の確 立が重要と考えられる.日射モデルおよび日射変動による 発電特性をモデル化し，実験と比較した .両者は良く一致 し, 動的モデルの有効性か確認された .

このモデルを敷衍すると，徒に接合数を増大しても年間 発電量は増大するとは限らないといった従来の定説を覆 す結論が暗示される.動的計画法を用いて日射変動を前提 とした最適バンドギャップの組み合わせを計算した結果， 5 接合以上では接合数を増やしても年間平均発電効率は 増大しないことが見いだされた，動的な理論効率平均値と しては $50 \%$ \%゙あり，実現可能な年間発電効率としては 40 \%が見込まれる .

この理論効率限界は, 直列回路を構成する接合の外部電 流が, 最も小さい電流源により制約されるといったキルヒ
フォッフの法則に由来する・したがって, 過剩電流を取り 出す工夫を施せば静的理論効率に匹敵する年間発電効率 を取り出すことが可能であろうと予想されるが, 残念なが ら現時点では決定打は出ていない .

\section{8.謝辞}

本研究の一部は, 経済産業省のもと, 独立行政法人新工 ネルギー・産業技術総合開発機構 (NEDO 技術開発機構) から委託され，実施したもので関係各位に感謝する．

\section{(文 献)}

1)M. Yamaguchi, A. Luque: IEEE Trans. Elec. Dev., 46-10 (1999), 2139.

2)荒木建次,山口真史: 電気製鋼, 71 (2000),303.

3)K. Araki, M. Yamaguchi, T. Takamoto, E. Ikeda, T. Agui, H. Kurita, K. Takahashi, T. Unno: Solar Energy Materials \& Solar Cells, 69 (2001), 559.

4)T. Takamoto, T. Agui, K. Kamimura, M. Kaneiwa, M. Imaizumi, S. Matsuda, M. Yamaguchi: Proc. $3^{\text {rd }}$ WCPEC, (2003), 581.

5)J. Gordon, Private Communication, (2004).

6) S. Ward, M. W. Wanlass, K. A. Emery, T. J. Coutts: Proc. 23rd IEEE PVSC, (1993), 650.

7)M. W. Wanlass, T. J. Coutts, J. S. Ward, K. A. Emery, T. A. Gessert, and C. R. Osterwald: Proc. 22nd IEEE PVSC, (1991), 38.

8)M. Yamaguchi, T. Takamoto, and S. Wakamatsu: Proc. $2^{\text {nd }}$ WCPEC, (1998), 3524.

9) S.R. Kurtz, D. Myers, J.M. Olson: Proc. $26^{\text {th }}$ IEEE PVSC, (1997),875.

10) S.R. Kurtz, P. Faine, J.M. Olson: J. Appl. Phys., 68(1990), 1890.

11)I.V. Karpova, S.G. Kalashnikov: International Conf. on Physics of Semiconductors, (1962), 880.

12)H.F. MacMillan, B.C. Chung, H.C. Hamaker, N.R. Kaminar, M.S. Kuryla, M. Landle Ristow, D.D. Liu, L.D. Partain, J.C. Schultz, G.F. Virshup, and J.G. Werthen: Solar Cells, 27 (1989), 205.

13)M. Yamaguchi, K. Araki: Proc. $29^{\text {th }}$ IEEE PVSC Conf., (2001), 820.

14)平成14年度新エネルギー・産業技術総合開発機構委託業 務成果報告書, 太陽光発電技術研究開発, 先進太陽電池技 
術研究開発, 超高効率結晶化合物系太陽電池モジュール 製造技術開発，大同特殊鋼，(2003）,118.

$15)$ N. J. Ekins-Daukes, Y. Kemmoku, K. Araki, T. R. Betts, R. Gottshlag, M.Yamaguchi: 第11回「高効率太陽電池および 太陽光発電システム」ワ -クショップ予稿(2003),83.

16)http://www.sharp.co.jp/sunvista/.

17) A. S. Brown, M. A. Green: Proc. $29^{\text {th }}$ IEEE PVSC, (2002), 868.

18) N.J. Ekins-Daukes, K. Araki, M. Yamaguchi: Proc. $14^{\text {th }}$ PVSEC, (2003) to be published.

19)荒木建次，山口真史: 第9回「高効率太陽電池および太陽 光発電システム」ワ-クショップ予稿(2001). 